\title{
Erik Bergman, Cosmopolitanism and the Transformation of Musical Geography ${ }^{1}$
}

Björn Heile

Erik Bergman (1911-2006) was without a doubt a modernist composer. He engaged and at times battled with many of the defining musical techniques of the twentieth century, from the postromantic nationalism of his earliest works, through a brief dabbling with neoclassicism, the adoption of dodecaphony in the early 1950s, followed soon after by integral serialism and controlled aleatoricism to the experimental exploration of sound of his often austere late works. Despite this almost suspiciously neat match between individual stylistic development and the general trajectories of canonic music history, a detailed engagement with Bergman's work troubles any whiggish textbook history of musical modernism as a linear story of innovation and progress. To be fair, such accounts no longer bear the authority once accorded to them, but what an investigation of Bergman's work brings to light is not simply the asynchronicity and diversity of twentieth-century music history or the difficulty of establishing clear criteria for what could be considered 'avantgardist', 'progressive', 'mainstream', 'traditional' or 'conservative', 'dominant' or 'marginal' at any given historical moment. Rather, what emerges most clearly is that modernism has to be thought of as a geographically as much as historically defined phenomenon. Bergman's music engages with musical geography in at least two ways: by unambiguously embracing modernism from a position at the very periphery of modernism and European culture more widely, and by drawing on non-western traditions. In other words, Bergman's music problematizes what the postcolonial critic Homi Bhabha has called 'The Location of Culture'.2

In the following, after sketching relevant theoretical approaches to the cultural geography of musical modernism, I provide an account of Bergman's career as the progressive development of a cosmopolitan vision. While, in common with other recent commentators, I draw on the burgeoning field of cosmopolitan studies - or more specifically, critical cosmopolitanism - to address certain blind spots of historical musicology and present Bergman's work as a case study, I am mindful of Ryan Minor's cogent warning

\footnotetext{
${ }^{1}$ Much of the material for this chapter was first presented in a keynote lecture at the Bergman Centenary Conference, Åbo Akademi, Turku (Finland), in September 2011. I wish to thank Juha Torvinen for inviting me and the other delegates as well as the delegates at the 'Transformations of Musical Modernism' symposium for many stimulating comments. A generous grant from the Carnegie Trust for the Universities of Scotland enabled me to study Bergman's sketches and manuscripts at the Paul Sacher Stiftung (Basel, Switzerland). Thanks are also due to the PSS and the curator of the Erik Bergman Collection at the time, Ulrich Mosch. Finally, I wish to pay tribute to Gerard Delanty who first introduced me to Cosmopolitan Studies, at the University of Sussex, where I was based at the time.

${ }^{2}$ Homi Bhabha, The Location of Culture (London: Routledge, 1994).
} 
against a tendency for hagiography in musicological approaches to cosmopolitanism. ${ }^{3}$ As will be seen, my general sympathy for Bergman does not occlude aspects that I find problematic or even disturbing. Yet, this too is instructive from a cosmopolitan perspective: although cosmopolitanism is driven by a normative ethics, this does not mean that there is a simple consensus on what represents a perfectly cosmopolitan act in any given situation. On the contrary, cosmopolitan ethics is procedural, and it is based on negotiation and mediation. Intercultural communication is fraught with difficulties and dangers, but the response cannot be to avoid it altogether. In a globalised world, trying and failing may be preferable to not engaging with the other at all.

\section{The Place of Musical Modernism}

Despite a spate of publications on broadly related topics, historical musicology has typically found it difficult to conceive of cultural geography. ${ }^{4}$ One reason for this blindspot may be found in the traditional division between historical musicology and ethnomusicology, as if a neat separation of history and geography, time and place were possible. Another may be found in the ideology of universalism, a disavowal of cultural difference, which is arguably foundational for Western classical music and which has rarely been interrogated. It is instructive, therefore, to look at accounts of Western classical music from outside musicology. The following excerpt is from a textbook in cultural geography, by Mike Crang: ${ }^{5}$

The geography of music has often contrasted local and universal, rootless and rooted. It has thus been led into a search for regional folk types - the mapping of styles and influences.

This treatment of music as embedded in a locale differs starkly from the classical music where traces of the local have been gradually removed. Classical music has tended to treat itself as a universal, neutral standard - folk and ethnic music are measured as deviations from it. While notable developments occurred in specific places and at specific times, it is suggested the qualities of the music transcend this. Rather like the model of classical science, music became marked by its reproducibility. And just as in science this entailed the spread of particular spaces of controlled conditions and techniques -

\footnotetext{
${ }^{3}$ Ryan Minor, 'Beyond Heroism: Music, Ethics, and Everyday Cosmopolitanism', Journal of the American Musicological Society 66, no. 2 (2013): 529-34.

${ }^{4}$ Examples of recent approaches to cultural geography from within historical musicology include Erik Levi and Florian Scheding, Music and Displacement: Diasporas, Mobilities, and Dislocations in Europe and Beyond (Scarecrow Press, 2010); Brigid Cohen, Stefan Wolpe and the Avant-Garde Diaspora, New Perspectives in Music History and Criticism (Cambridge: Cambridge University Press, 2012); Dana Gooley, 'Cosmopolitanism in the Age of Nationalism, 1848-1914', Journal of the American Musicological Society 66, no. 2 (1 August 2013): 523-49, doi:10.1525/jams.2013.66.2.523; Brigid Cohen, 'Limits of National History: Yoko Ono, Stefan Wolpe, and Dilemmas of Cosmopolitanism', The Musical Quarterly, 17 October 2014, gdu008, doi:10.1093/musqtl/gdu008, among others.

${ }^{5}$ Mike Crang, Cultural Geography, Routledge Contemporary Human Geography Series (London: Routledge, 1998), 90-1.
} 
laboratories - in classical music there is the spread of the concert halls and particular practices of listening.

This quotation is hardly free from problematic generalisations, and it is easy to pick holes in it. What about, for instance, the local and national styles in the eighteenth century or nationalism in the nineteenth? Even standard histories of music allow for some national or regional variation, say when covering the specifically French tradition of tragédie lyrique, and 'art' music rarely lost touch with vernacular popular traditions entirely, witness the infatuation with folk and popular dance music from Ländlers to tangos and beyond. But, simplified as his account may be, Crang surely has got a point. Note too that the objections made above could with some justification be described as local variants of an underlying universal phenomenon or, in the case of nationalism, as an 'invented tradition'. ${ }^{6}$

The most influential textbook in music history, Richard Taruskin's Oxford History of Western Music, has next to nothing to say about what constitutes the 'west' in the title, other than to suggest that it encompasses Europe and 'America' (whether he means the continent, the USA or North America is not clear), ${ }^{7}$ and, although Taruskin has been rightly praised for raising the profile of Russian and Eastern European music, he remains almost entirely silent about the music of Latin America and Asia, not to mention Africa. Surely, the expansion of this form of music from the heartlands of Europe to, progressively, the entire world is a remarkable phenomenon which is worth studying in its own right and which forms a central element of its history. ${ }^{8}$ Why did the elites (for it was usually primarily them) in such diverse places as Russia, North and South America, Japan, Korea and China embrace this music, and why did newly independent or modernising states feel the need to set up conservatoires and symphony orchestras as tokens of statehood almost on a par with flags, passports and currencies? And why did forms of musical modernism, in whatever guise, gain a foothold in countless countries and regions around the world? The answers to these questions have to do with geopolitics, colonialism and globalisation, and, although this is not the place to go into detail, it is my contention that as the product of these forces, Western classical music bears their imprint. Indeed, the adjective 'Western' has to be called into question, given the long history of adoption and adaptation of this music outside the West (which is itself an increasingly questionable construct). Nor can we assume that these developments at the 'margins' had no effect on the 'centre'. The history of musical modernism may therefore be one not only of geographic expansion but also of diversification and hybridisation.

\footnotetext{
${ }^{6}$ See E. J. Hobsbawm and T. O. Ranger, eds., The Invention of Tradition (Cambridge: Cambridge University Press, 1983).

${ }^{7}$ Richard Taruskin, The Oxford History of Western Music (Oxford ; New York: Oxford University Press, 2005), xxi.

${ }^{8}$ This argument is indebted to Nicholas Cook and Anthony Pople's Cambridge History of Twentieth-Century Music, which, quite uniquely, reflects deeply on the transformations of modernist musical geography; see Nicholas Cook, 'Introduction: Trajectories of Twentieth-Century Music', in The Cambridge History of TwentiethCentury Music, ed. Nicholas Cook and Anthony Pople (Cambridge: Cambridge University Press, 2004), 7-9.
} 
It is noticeable, therefore, that terms such as 'globalisation' and 'colonialism' or 'postcolonialism' are rarely encountered in historical musicology. By contrast, they are hotly debated in ethnomusicology: there is wide agreement that traditional and popular music are subject to these forces, but the assumption appears to be that classical and modernist music are not. An (apparent) exception to this rule is the study of musical exoticism and orientalism. ${ }^{9}$ Although this undoubtedly represents a valuable contribution, it remains a somewhat limited engagement with musical otherness. At heart, this type of research is about the Western self; the non-Western other figures only in its represented form. ${ }^{10} \mathrm{It}$ cannot talk back. The wider questions about musical constructions of self and other are rarely asked, and the very concepts of Western and non-Western remain unquestioned. ${ }^{11}$

An interesting case in point of the difficulty in theoretical approaches to the cultural geography of musical modernism is the infamous footnote in Adorno's Philosophy of New Music: ${ }^{12}$

Where the developmental tendency of occidental music was not fully carried through, as in many agrarian regions of southern Europe [orig. 'south-eastern Europe'], it has been possible right up to the present [orig. 'most recent past', jüngste Vergangenheit] to use tonal material without opprobrium. Mention may be made here of the extraterritorial, yet in its rigor magisterial, art of Leoŝ Janáček, as well as much of Bartók's, who in spite of his folkloristic penchant at the same time counted among the most progressive composers in European art music. The legitimation of such music from the periphery in every case depends on its having developed a coherent and selective technical canon. In contrast to the productions of Nazi blood-and-soil ideology, truly extraterritorial musicwhose material, while common in itself, is organized in a totally different way from occidental music-has a power of alienation that associates it with the avant-garde and not with nationalistic reaction. Ideological blood-and-soil music, by contrast, is always affirmative and allied with "the tradition," whereas it is precisely the tradition of all official music that is suspended by Janáček's diction, even in the midst of all the triads.

Clearly Adorno is troubled by music which does not fit into his universalist account, but which, to his credit, he appreciates. His response is the recourse to the traditional geography of centres and peripheries (although his usage of 'extraterritorial' overstates even that case), whereby, as in the classic account by Kenneth Clarke, ${ }^{13}$ the technical

\footnotetext{
${ }^{9}$ See Jonathan Bellman, The Exotic in Western Music (UPNE, 1998); Ralph P. Locke, Musical Exoticism: Images and Reflections (Cambridge ; New York: Cambridge University Press, 2009), among others.

${ }^{10} \mathrm{Cf}$. Sindhumathi Revuluri, 'Review: Musical Exoticism: Images and Reflections', Journal of the American Musicological Society 64, no. 1 (1 April 2011): 253-61, doi:10.1525/jams.2011.64.1.253.

${ }^{11} \mathrm{~A}$ corollary of musicology's obsession with exoticism is the prominence given to Edward Said's Orientalism Orientalism (London: Penguin Books, 2003).. This is not to deny the significance of the book, but it is hardly the only example of postcolonial scholarship with relevance for musicology.

${ }^{12}$ Theodor W. Adorno, Philosophy of New Music (Minneapolis ; London: University of Minnesota Press, 2006), 176.

${ }^{13}$ Cited in Franco Moretti, Atlas of the European Novel, 1800-1900 (London: Verso, 1998), 164.
} 
standard in the periphery is behind that of the centres according to a spatio-temporal logic. This thinking in terms of centres and peripheries, which is key to the history of musical modernism, is not necessarily innocent, mirroring as it does the spatial order of colonialism. This would explain the centrality of the notion of 'time-lag', which in one sense can be interpreted as that between the metropolis and the colony, in the thought of Bhabha, for instance. $^{14}$

In any case, it is easy to see that Adorno's treatment of the music of Janáček and Bartók as an exception to 'the developmental tendency of occidental music' is hardly adequate; the more far-reaching response would be to interrogate the concepts of 'developmental tendency' and/or 'occidental music' so that they may accommodate them. To be fair, more recent approaches have generally had little difficulty in including Janáček and Bartók, but that does not mean that the problem of centres and peripheries and of music that 'doesn't fit' the narrative as a consequence has gone away; it has only been pushed further to 'the margins', witness the unreflected restriction to America and Europe in Taruskin. ${ }^{15}$ Although it would be wishful thinking to confine centres and peripheries firmly to the past, there is wide agreement that this model is inadequate in dealing with the cultural dynamics of globalisation. ${ }^{16}$

For approaches to modernism which acknowledge the formative function of place and the history of colonialism, decolonisation and globalisation, one has to look largely beyond musicology at literary studies. ${ }^{17}$ As mentioned above, however, there has been a recent surge in approaches to modernist music which resemble mine in crucial aspects. One of the most far-reaching and the most relevant in the present context are Brigid Cohen's studies of Stefan Wolpe and, more recently, Wolpe and Yoko Ono. ${ }^{18}$ Like me, Cohen also bases her account on cosmopolitan studies. Although I am in full agreement with her approach, some of my emphasis here is slightly different. Cohen focuses on the importance of migration for modernism and the contributions made by migrants, represented by Wolpe and Ono. As someone who has worked on another prominent migrant, Mauricio Kagel, and as an immigrant myself (albeit one of opportunity rather than necessity), I am more than sympathetic to this approach. Nevertheless, in my view migration is not the only, and not necessarily the most significant, aspect of the cultural geography of music overlooked by the continuing dominance of national history which Cohen deplores. Moreover, for cosmopolitanism to function as an ethics, it must not be regarded as the preserve of either the privileged or the unfortunate. After all, it was Kant, who famously never moved far from his native Königsberg, who based cosmopolitanism on the principle of 'universal

\footnotetext{
${ }^{14}$ Bhabha, The Location of Culture, 338-67.

${ }^{15}$ Taruskin, The Oxford History of Western Music (see fn. 7).

${ }^{16}$ See, for example, Arjun Appadurai, Modernity at Large: Cultural Dimensions of Globalization (Minneapolis, Minn. ; London: University of Minnesota Press, 1996), 32.

${ }^{17}$ Laura Doyle and Laura A. Winkiel, Geomodernisms: Race, Modernism, Modernity (Indiana University Press, 2005); Peter Brooker and Andrew Thacker, eds., Geographies of Modernism: Literatures, Cultures, Spaces (London; New York: Routledge, 2005).

${ }^{18}$ Cohen, Stefan Wolpe and 'Limits of National History'.
} 
hospitality' ${ }^{19}$ In other words, it is not only or not necessarily the refugee who is cosmopolitan but the one who gives her shelter, not the traveller but his host. As Bhabha has put it, 'cosmopolitanism must always begin at home!'. ${ }^{20}$ Although it may come more naturally to some of us than others, we can all be cosmopolitan. As we will see, Erik Bergman travelled frequently and widely, and, at least in later years, was able to do so due to his relative wealth and the privileges provided by a first-world passport. But his interest in and openness towards others preceded his journeys; he travelled because he was cosmopolitan by instinct if not persuasion, he did not become cosmopolitan as a result of travel (even if that experience may have confirmed his beliefs).

Although this is not the place for a comprehensive account of cosmopolitanism or its significance for music, some brief remarks on the idea of cosmopolitanism employed in this chapter are in order, notably since the scholarly concept diverges quite widely from the everyday use of the term, which can lead to confusion. ${ }^{21}$ In the words of Anthony Appiah, cosmopolitanism 'begins with the simple idea that in the human community, as in national communities, we need to develop habits of coexistence: conversation in its older meaning, of living together, association'. ${ }^{22}$ There are two principles to this: '[o]ne is the idea that we have obligations to others, obligations that stretch beyond those to whom we are related by the ties of kith and kind, or even the more formal ties of a shared citizenship', and 'the other is that we take seriously the value not just of human life but of particular human lives, which means taking an interest in the practices and beliefs that lend them significance' ${ }^{23}$ Over and above these points, the principles and values of cosmopolitanism are hotly debated and widely contested not only between its opponents and proponents but also among the latter. Nevertheless, there seems to be an almost concerted effort to disprove certain popular prejudices, namely that it is essentially Western or that it is primarily associated with privilege and multinational corporations. For instance, James Clifford has argued that 'the project of comparing and translating different travelling cultures need not be class- or ethnocentric', looking for instance, at the experiences of Pakistani labourers in Gulf countries. ${ }^{24}$ Critical cosmopolitanism, in particular, is intended as an ethical corrective to the

\footnotetext{
${ }^{19}$ Immanuel Kant, Perpetual Peace (Filiquarian Publishing, LLC., 2007), 21.

${ }^{20}$ Bhabha, The Location of Culture, $\mathrm{xv}$.

${ }^{21}$ Despite their undoubted merits, some earlier accounts of cosmopolitanism in music, notably Stokes 'On Musical Cosmopolitanism', The Macalester International Roundtable 2007, 26 September 2007, http://digitalcommons.macalester.edu/int/rdtable/3. and Magaldi 'Cosmopolitanism and World Music in Rio de Janeiro at the Turn of the Twentieth Century', The Musical Quarterly 92, no. 3-4 (21 September 2009): 32964, doi:10.1093/musqtl/gdp021., suffer from the somewhat uncritical employment of everyday notions of cosmopolitanism.

${ }^{22}$ Anthony Appiah, Cosmopolitanism: Ethics in a World of Strangers (New York: W.W. Norton, 2006), xix.

${ }^{23}$ Ibid., Xv.

${ }^{24}$ Quoted in Pnina Werbner, 'Anthropology and the New Ethical Cosmopolitanism', in Routledge Handbook of Cosmopolitan Studies (Abingdon, Oxon: Routledge, 2012), 156. See also Carol Appadurai Breckenridge, ed., Cosmopolitanism, Millennial Quartet (Durham [N.C.] ; London: Duke University Press, 2002); Fuyuki Kurasawa, 'A Cosmopolitanism from Below: Alternative Globalization and the Creation of a Solidarity without Bounds', European Journal of Sociology / Archives Européennes de Sociologie 45, no. 02 (August 2004): 233-55, doi:10.1017/S0003975604001444; Pnina Werbner, 'Global Pathways. Working Class Cosmopolitans and the Creation of Transnational Ethnic Worlds', Social Anthropology 7, no. 01 (February 1999): 17-35.
} 
unregulated process of globalisation and, in common with critical theory, with which it explicitly aligns itself, is aimed at transforming the present, over and above describing it. ${ }^{25}$

Most significant for our purposes is cosmopolitanism's conflicted stance towards universalism and diversity or relativism. Although Chernilo, for instance, has defended certain conceptions of universalism from a cosmopolitan perspective (though his heavy qualification should be noted) ${ }^{26}$ most cosmopolitan thinkers reject such an association, stressing on the contrary that, in the words of Hannerz, cosmopolitanism 'includes an aesthetic stance of openness towards divergent cultural experiences, a search for contrasts rather than uniformity', whereas universalism assumes sameness. ${ }^{27}$ Likewise, Bhabha has associated cosmopolitanism with Julia Kristeva's notion of a 'right to difference in equality', ${ }^{28}$ and Fred Dallmayer has proposed a 'hermeneutics of difference' which would negotiate between Enlightenment and modernist ideas of universalism on one hand and postmodernist and postcolonial notions of identity politics on the other. ${ }^{29}$ In a similar way, most proponents are at pains to stress that forming allegiances with distant others does not mean repudiating local ties. Indeed, several commentators have called for 'rooted cosmopolitanism' or, like Bhabha, 'vernacular cosmopolitanism'. ${ }^{30}$ Denigrating the local and particular in favour of the distant and universal is therefore not a cosmopolitan position. As will be seen, I believe that Bergman's practices embodied many of these precepts (if I insist on 'practices' over his professed beliefs, it is not only because 'actions speak louder than words', but also because I have to admit that I know relatively little about the latter, although my views at least do not conflict with published accounts and have met with agreement from those who knew him better).

It goes without saying that Bergman is not necessarily the only or even the best example of a cosmopolitan perspective in modernist music. Nor, as I think my earlier remarks have made clear, do I think that there can be a stable or uncontroversial definition of what constitutes 'cosmopolitanism in music'. In conclusion of this section, I would like to point to two instances of a cosmopolitan attitude in musical life (rather than composition more narrowly) from the first half of the twentieth century. The first concerns Paul Bekker, who coined the term 'new music', ${ }^{31}$ which Adorno later adopted, and who argued forcefully for

\footnotetext{
${ }^{25}$ Gerard Delanty, 'The Idea of Critical Cosmopolitanism', in Routledge Handbook of Cosmopolitan Studies, ed. Gerard Delanty (Abingdon, Oxon: Routledge, 2012), 38-46.

${ }^{26}$ Daniel Chernilo, 'Cosmopolitanism and the Question of Universalism', in Routledge Handbook of Cosmopolitan Studies, ed. Gerard Delanty (Abingdon, Oxon: Routledge, 2012), 47-59.

27 Ulf Hannerz, 'Cosmopolitans and Locals in World Culture', Theory, Culture \& Society 7, no. 2 (6 January 1990): 239, doi:10.1177/026327690007002014. See also Ulrich Beck, The Cosmopolitan Vision (Cambridge: Polity Press, 2006), 48-53.

${ }^{28}$ Bhabha, The Location of Culture, xvii.

${ }^{29}$ Fred Reinhard Dallmayr, Beyond Orientalism: Essays on Cross-Cultural Encounter (SUNY Press, 1996), xi.

${ }^{30}$ See Pnina Werbner, 'Anthropology and the New Ethical Cosmopolitanism', in Routledge Handbook of Cosmopolitan Studies (Abingdon, Oxon: Routledge, 2012), 154 for rooted and Homi Bhabha, 'Unsatisfied: Notes on Vernacular Cosmopolitanism', in Text and Nation, ed. Laura Garcia-Morena and Peter C. Pfeifer (London: Camden House, 1996), 191-207 for vernacular cosmopolitanism.

${ }^{31}$ Paul Bekker, Neue Musik (Kraus Reprint, 1920).
} 
an 'amalgamation of cultured humanity'32 and, although he seemed to be instinctively more drawn to the likes of Mahler and Schoenberg, consistently tried to be similarly generous to Debussy, Stravinsky and others, apparently reflecting on and countering his own instincts (in ways Adorno signally failed to do). Similarly, for all its flaws, the International Society for Contemporary Music attempted to break down national barriers and to promote '[a]rtistic diversity in musical creation, without prejudice on differences in musical expressions, styles, genres or media; nor regarding race, religion or politics'. ${ }^{33}$ I would argue that it is these kinds of views to which Bergman's work seems to be committed.

\section{Cosmopolitanism I: from Nationalism to Internationalism}

Despite the problematic nature of the centre-periphery model implicit in standard music historiography, any account of Bergman's career and work has to reckon with the peripheral nature of musical life in Bergman's native Finland in the first half of the twentieth century, which, despite (or maybe because of) the stature of Sibelius and the efforts of earlier modernists, such as Aarre Merikanto, by most accounts was considerably more provincial than Janáček's Brno or Bartók's Budapest to which Adorno alluded. ${ }^{34}$ Indeed, although his training and career took place in Helsinki, Bergman was actually from Nykarleby (Uusikaarlepyy) in Ostrobothnia in Western Finland and, like Sibelius, was a member of the Swedish minority. Although Finland-Swedes were traditionally part of the elite (from the time of the Swedish empire) and are well integrated, their status is slightly precarious. All in all, it is not surprising that Bergman started off in a style that was pretty much mandatory, not only in Finland, but with some variation, in many other regions and countries like it: romantic nationalism, to be superseded before long by dabbling in neo-classicism. So far, so predictable.

He wanted more, however, and, at that time and in that place, this meant going abroad. According to Ulrich Mosch, it was Max Trapp, then on tour in Finland, who recommended that he study with Fritz Tiessen. ${ }^{35}$ Bergman's studies with Tiessen between 1937 and 1939 and again 1942-43 are mentioned in every biographical sketch - with astonishing equanimity, as if there is nothing unusual about a composer being drawn to Nazi Germany of all places, and, on the second occasion, during the height of the war, of all times. Things are somewhat murky: while Trapp was pretty much an impeccable Nazi, having joined the NSDAP well before Hitler assumed power, ${ }^{36}$ Tiessen was actually from the political left; he had been a member of the Novembergruppe of expressionist artists (named after the

\footnotetext{
32 Paul Bekker, Gesammelte Schriften, 1921, 182.

${ }^{33}$ International Society for Contemporary Music, Statutes 2010, Art. 6, accessed 15 December 2014, http://www.iscm.org/sites/default/files/rules_and_forms/Statutes\%202010.pdf.

${ }^{34}$ Cf. Tim Howell, After Sibelius: Studies in Finnish Music (Aldershot ; Burlington, VT: Ashgate, 2006); Kalevi Aho et al., Finnish Music (Keuruu: Otava, 1996).

35 “"Ihre Lieder Sind Stimmungsvoll Und Schön, Nur...": Erik Bergmans Studien Bei Heinz Tiessen Zwischen 1937 Und 1943', Mitteilungen Der Paul Sacher Stiftung 24 (2011): 12.

${ }^{36}$ Fred K. Prieberg, Handbuch deutsche Musiker 1933-1945 (Fred K. Prieberg, 2004), 7226-31.
} 
November Revolution in the Soviet Union) as well as the socialist Arbeitersängerbund. ${ }^{37}$ While his career did not entirely end under the Nazis, he was not a major opportunist and undertook little to shake off the suspicion with which he was viewed. Why Trapp would have recommended a political enemy is difficult to see, although both composers shared similar stylistic tendencies (somewhere between Richard Strauss and Hindemith) - which, incidentally, says much about the political signification of musical style. The current state of knowledge about Bergman's activities in the Third Reich is thus quite confusing, and there is clearly a need for further research.

As is well known, Bergman subsequently became the first Finnish composer to employ dodecaphony, then virtually unknown in Finland, in the Espressivo Op. 40 for piano (in 1952). There is no evidence, however, that the learned the technique from Tiessen, and the long period between his study periods with him and Bergman's first dodecaphonic works make this connection unlikely. Despite a lack of experience and available models, the following Three Fantasies Op. 42 for Clarinet and Piano (1953-1954) are without doubt an accomplished composition. Nevertheless, his understandable difficulties with twelve-note technique led him to study with Wladimir Vogel in Ascona, another pupil of Tiessen's and veteran of the left-wing Novembergruppe. Again, like Tiessen, Vogel was, although respected, hardly at the centre of musical developments. However, he was a recognised specialist in dodecaphony, having organised the international twelve-tone music preconference in Osilina (1949), attended by Dallapiccola, Malipiero and others. ${ }^{38}$

Bergman's use of serial techniques can be reconstructed comparatively easily on the basis of his sketches and manuscripts, which are collected at the Paul Sacher Stiftung (Basel). Although this is not the primary focus of this chapter, it is necessary to clear up some misunderstandings in the existing research on this area and to contextualise his work more firmly in relation to the prevailing trends of the time. In many cases, Bergman wrote out row tables and even highlighted serial strands in his sketches. Although Heiniö and Oramo, in their respective entries on the composer in Komponisten der Gegenwart and Musik in Geschichte und Gegenwart, both state that Bergman used the series vertically and non-thematically, ${ }^{39}$ the sketches and manuscripts reveal that, particularly in later years, he often preferred linear exposition of the series. The Adagio Op. 47a for Baritone, Flute, Male Choir and Vibraphone (1957), for instance, features horizontal unfolding of the series throughout, starting with a quasi-canon in the choir on different transpositions of the prime form of the series. Nor is it strictly true that Bergman's serial phase ended in 1962, as Aho claims: ${ }^{40}$ serial elements are in evidence at least up to Circulo Op. 58 (1965), although it is true that, at least on the surface, serialism played a progressively less important role in Bergman's compositions from the 1960 s onwards.

\footnotetext{
37 Ibid., 7192-5.

${ }^{38}$ Tamara Levitz, 'Vogel, Wladimir', Grove Music Online, n.d.

${ }^{39}$ Mikko Heiniö, 'Bergman, Erik', ed. Hanns-Werner Heister and Walter-Wolfgang Sparrer, Komponisten Der Gegenwart, 10. Lfg. (Munich: Edition Text + Kritik, n. d.); Ilkka Oramo, 'Bergman, Erik', Die Musik in Geschichte Und Gegenwart, n. d.

${ }^{40}$ Kalevi Aho, 'Bergman, Erik', Komponisten der Gegenwart, 32. Lfg., 2006.
} 
The design of the rows themselves is also quite sophisticated, frequently involving specific intervallic characteristics or symmetrical structures. The row for Aubade Op. 48 for orchestra (1958) is an interesting case in point. It is neatly divided into two hexachords (see ex. 1), with the second one being the transposed inversion of the first. Both hexachords consist entirely of tritones and major seconds; indeed, they each make up a whole-tone set. In the course of the composition, Bergman mostly works with individual hexachords, rather than the twelve-note row as a whole. This is in fact a common trait of his mature serial practice, as indeed of serial composition in general, illustrating that he was by that point well informed about common trends and skilled in their application.

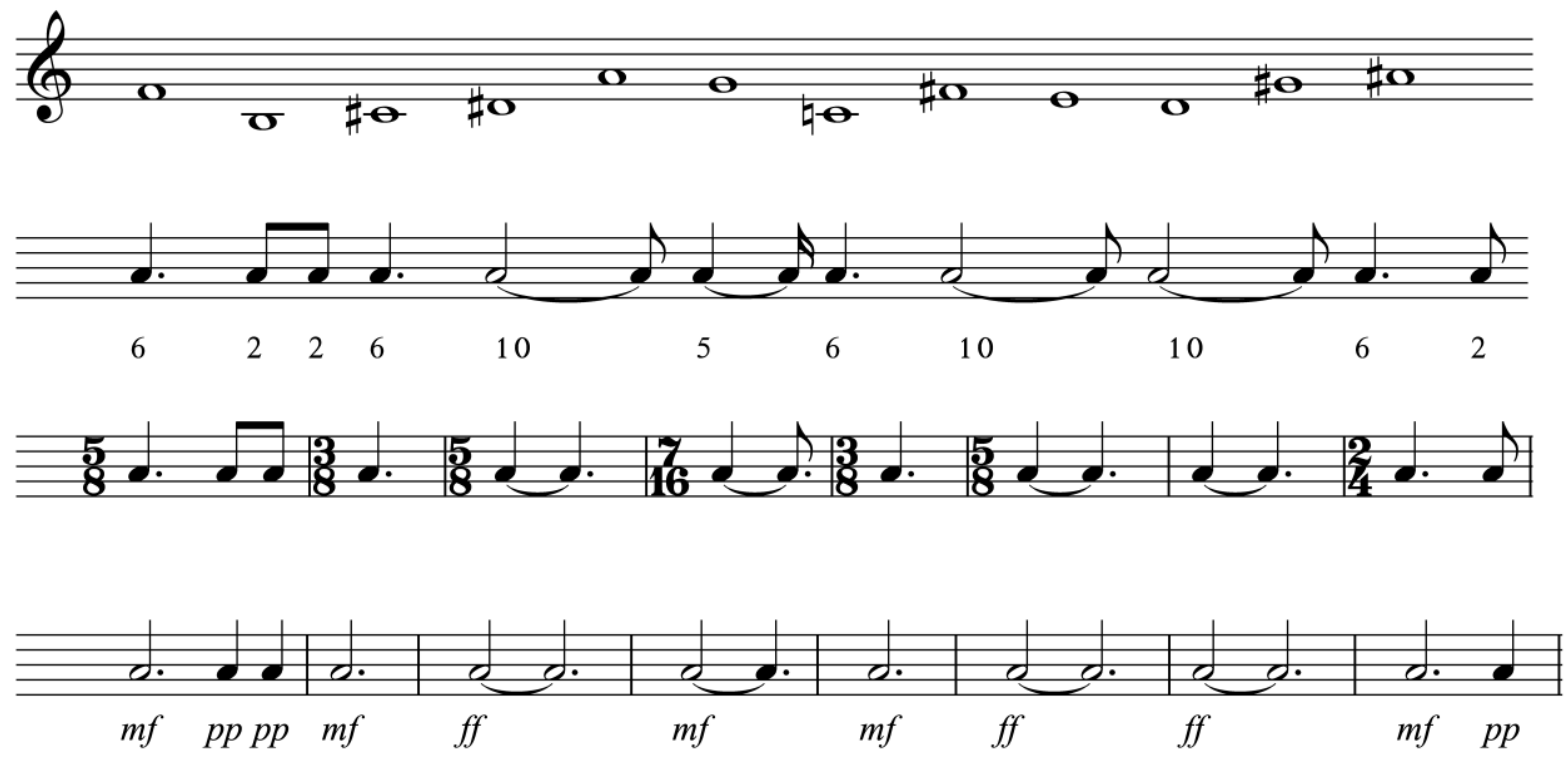

Ex. 1: Serial structure of Erik Bergman's Aubade for Orchestra Op. 48.

Indeed, he had visited the Darmstadt summer courses during the previous year, 1957, ${ }^{41}$ attending Luigi Nono's and Karlheinz Stockhausen's lectures: 'Die Entwicklung der Reihentechnik' ('The Development of Serialism') in Nono's case and 'Music and Language' (Stockhausen), the latter including a brilliant, albeit misguided, analysis of Nono's // Canto sospeso. ${ }^{42}$ This seems to have been Bergman's only direct encounter with the international avant-garde in one of its centres, however.

Another fairly predictable result of this experience can also be found in Aubade: the application of integral serialism (seemingly for the first time in Bergman's work). Again the sketches reveal the process clearly. Bergman derived rhythmic and dynamic values from the intervals in the pitch series in a fairly basic way. For durations, a minor second upwards is defined as a semi-quaver, with all larger intervals being multiples thereof (this obviously

\footnotetext{
41 John David White and Jean Christensen, New Music of the Nordic Countries (Pendragon Press, 2002), 155; Martin Anderson, 'Erik Bergman [Obituary]', The Independent, 9 May 2006, http://www.independent.co.uk/news/obituaries/erik-bergman-477409.html.

42 Martin Iddon, New Music at Darmstadt: Nono, Stockhausen, Cage, and Boulez, (Cambridge: Cambridge University Press, 2013), xix.
} 
only works for ascending intervals, so the falling major seconds in the series are reinterpreted as rising minor sevenths, yielding a duration of ten semiquavers). The dynamic values are applied in a similar way, with two (the lowest value occurring in the series) representing $\mathrm{pp}$, rising to ff (for the ascending minor seventh). Similar techniques are used in other pieces, such as Simbolo Op. 52 (1960), another orchestral composition. This is, however, only intermittently applied in the piece with any rigour; one such moment occurs in a passage marked poco meno allegro (bars 131ff.), which first presents only un-pitched percussion (playing serially generated rhythms) before the other instruments enter with a linear statement of $I_{3}$ split up between the instruments; this is followed by a gradual thickening of the orchestral texture (homophonically and polyphonically).

In much of the remainder of the piece, however, the serial structures are harder to follow, and Bergman seems to have employed them less strictly. This too appears to be a common trait in his oeuvre, although more systematic analysis would be required.

Although from the standpoint of serial technique alone Aubade is a relatively simple work, both in its serial ordering (notably the generation of rhythm) and application, compared to otherwise similar compositions from the time, such as Stockhausen's Gruppen (1956) or Nono's II canto sospeso (1956), it is undoubtedly a masterpiece and demonstrates that Bergman had learned the lessons from the serialist avant-garde with astonishing speed (very few composers at that, or any other, time went as far as Stockhausen of Nono in seeking to base the entirety of the musical structure from one serial kernel, nor should this be regarded as some kind of music-historical shibboleth). It must not be forgotten that he had only recently encountered dodecaphony and that he was already at an age when most other composers prefer to stick to what they know and master. In addition to his rejection of nationalism and embrace of what could be considered an 'international style' in music, it is Bergman's openness towards the new and willingness to learn (from much younger composers) that demonstrates his cosmopolitan spirit.

Although integral serialism is often depicted as a dull homogenising force, it presented exciting new ideas to many at the time, particularly in places with a hide-bound musical culture. As Paavo Heininen has pointed out, Bergman was 'the man to usher in the new wave of musical modernism in Finland [and] he was also responsible for bringing Finland into the mainstream of European avant-garde music by going further than the first generation of Finnish modernists, rejecting the expressive ideals and sound of romanticism and adopting a contextual [by which he means serial] compositional technique. ${ }^{43}$ This commitment to what Heininen calls (somewhat oxymoronically) 'the mainstream of European avant-garde music' has to be regarded as quite radical, and it led Bergman to become something like the adopted father of the 'Ears Open!' group of younger Finnish modernists (whose founders were Magnus Lindberg and Esa-Pekka Salonen), who, at last, also found wide recognition abroad. ${ }^{44}$ This wider international recognition has largely

\footnotetext{
${ }^{43}$ Paavo Heininen, 'Erik Bergman's Path to the New Music', in Erik Bergman: A Seventieth Birthday Tribute, ed. Jeremy Parsons (Helsinki: Pan, 1981), 113.

${ }^{44}$ Aho et al., Finnish Music, 138-41.
} 
remained elusive for Bergman himself: it is almost a cruel irony that self-exoticism is eminently saleable abroad, while avant-gardism tends to be less highly valued if it hails from what is perceived to be a periphery. A comparison with Bergman's younger contemporary Einojuhani Rautavaara is instructive in this regard. A parallel can be drawn with the Argentine composer Juan Carlos Paz, Bergman's senior by ten years, who was instrumental in bringing the international avant-garde to Latin America - he adopted twelve-note technique in $1934^{45}$ - but who failed to achieve a similar recognition abroad to someone like Alberto Ginastera, who was far more willing to play up to prevailing ideas of folkloristic nationalism - not to mention the strange career of Astor Piazzolla.

In the following years, Bergman also adopted forms of controlled aleatory technique. The dissemination of this technique is itself an interesting case of the cultural geography of new music. As Howell has pointed out, Bergman's use of the technique is most closely related to that of Witold Lutosławski; ${ }^{46}$ Lutosławski in turn got the inspiration from John Cage, although both the aesthetic intent behind the technique, and his technical employment of it, differ quite radically from that model. ${ }^{47}$ The key work most frequently mentioned in this respect is the haunting Colori ed improvvisazioni Op. 72 (1973) which abandons bar lines about half-way through the first of its three movements (see ex. 2), using time-space notation for the remainder of the work. What sets Bergman's work from this period apart is his varied, imaginative and practical use of notational techniques, with minutely differentiated degrees of variability and interpretive freedom with regard to pitch, duration and timbre. His vast experience as a choral director will almost certainly have played a role in this context. In relation to his employment, he also wrote numerous vocal compositions, in which he explored the possibilities of the human voice well beyond the norms of lyrical pitched singing, to include speaking, Sprechstimme and a host of gradations in between. These are by their nature often difficult to notate and indeterminate with respect to, for example, pitch. Bergman's practical experience would have given him an incomparable understanding of how different types of symbols are realised by singers and what effects they create (one is reminded of Duke Ellington who liked to experiment with his players and whose work as a composer can likewise not be separated from that of a bandleader). While the technical practicalities differ somewhat between different types of instruments and between instruments and voices, scores such as that for Bergman's opera Det Sjungande Trädet, Op. 110 (1988) illustrate that the composer used similar techniques for singers and

\footnotetext{
45 Omar Corrado, Vanguardias al sur: la música de Juan Carlos Paz (Univ. Nacional de Quilmes Ed., 2012).

${ }^{46}$ Howell, After Sibelius, 60.

${ }^{47}$ Witold Lutosławski, Lutosławski on Music (Rowman \& Littlefield, 2007), 42 and 99.
} 
instrumentalists in order to achieve comparable effects.
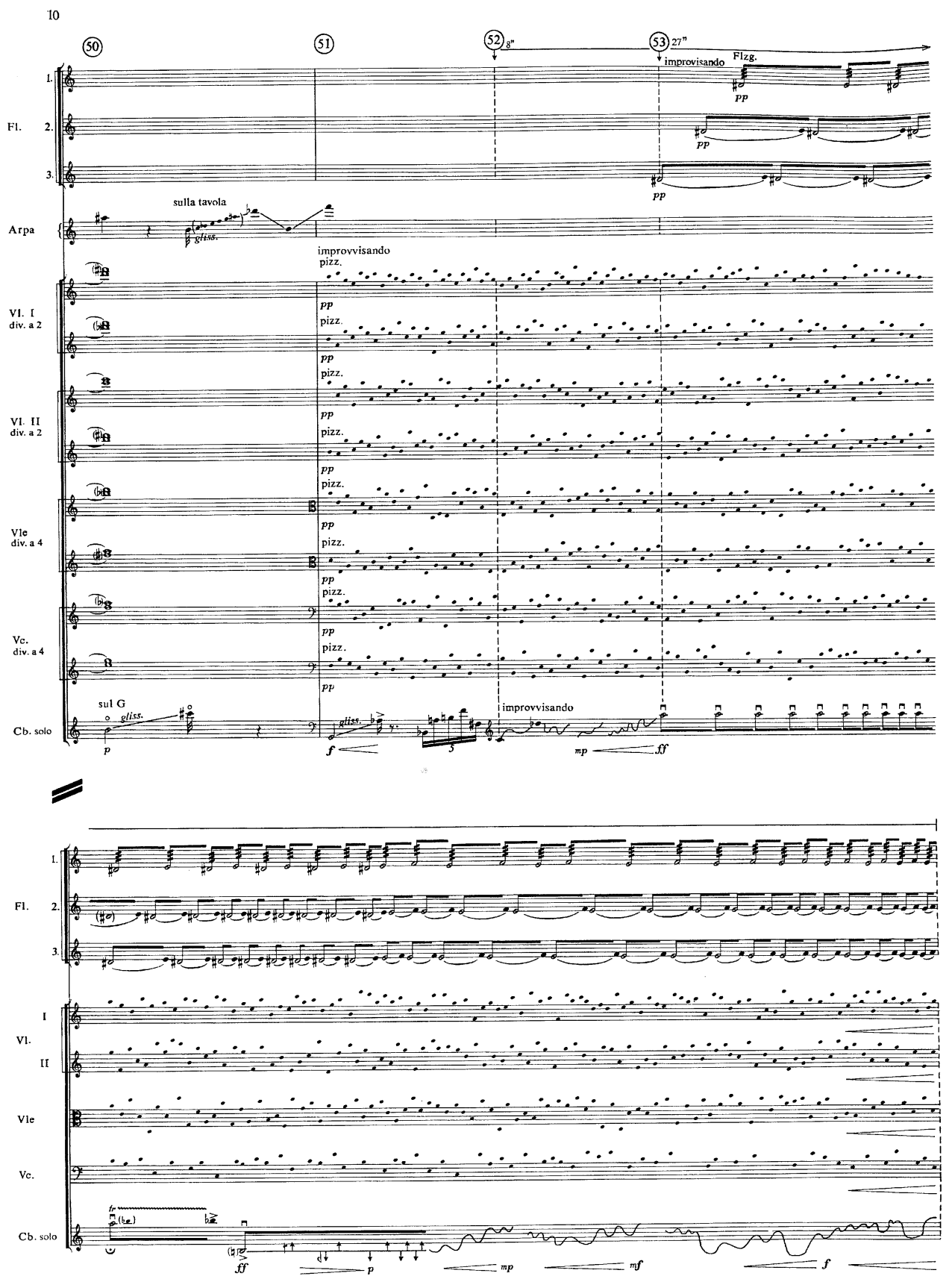

Ex. 2: Erik Bergman, Colori ed Improvvisazioni Op. 72, bars 50ff. Reproduced by permission of Boosey \& Hawkes Music Publishers Ltd 
What this survey demonstrates, then, is how Bergman throughout his compositional career responded creatively to and took part in musical developments from abroad. What has become clear is that his guiding principle in that was a musical internationalism, arguably a form of universalism. He seemed to have no truck with musical nationalisms or with any kind of special pleading. That doesn't mean that he slavishly followed whatever trend he perceived, but that he adopted and modified those developments that suited his own artistic ends. For what follows, it is important to recognise that this form of internationalism is not fully cosmopolitan in the way I am using the term, or only to a relatively limited extent (many theorists envisage degrees of cosmopolitanism). Likewise, the post-war avant-gardes like the 'Darmstadt school' are sometimes called cosmopolitan, but this reflects a colloquial usage of the term which I want to distinguish from the idea of cosmopolitanism exposed above. The reason the internationalism of the post-war avantgardes cannot be considered fully cosmopolitan is that they do not recognise cultural difference: they proclaim an unvarying absolute standard. Boulez's infamous remark that 'any musician who has not experienced ... the necessity of dodecaphonic music is USELESS' illustrates the point neatly. ${ }^{48}$ As pointed out above, although internationalist universalism could be considered an advance over nationalism from a cosmopolitan perspective, the cosmopolitan does not simply favour the global over the local or the universal over the particular.

\section{Cosmopolitanism II: Encountering the Other}

Following this line of argument, it is Bergman's complementation of the international with the global that marks his cosmopolitanism. What I am referring to is his interest in traditional and non-Western musics. Such an interest is often somewhat rashly and sweepingly equated with a colonialist or neo-colonialist mindset. ${ }^{49}$ As will become clear, although there are problematic aspects in his thinking, Bergman can be said to have developed an increasingly cosmopolitan approach. It may be somewhat surprising if I suggest that this fascination with non-Western music is already perceptible in his study of Catholic music at the Vatican in the 1950s. This music is of course not non-Western and it is seemingly related to Bergman's employment at the Roman-Catholic Church in Helsinki. Yet, for a Protestant Finland-Swede, the liturgical practices of the Vatican may seem quite foreign. In any case, from a cosmopolitan perspective, the binary division of the world into Western and non-Western and the consequent attribution of self and other along these

\footnotetext{
${ }^{48}$ Pierre Boulez, Stocktakings from an Apprenticeship (Clarendon Press, 1991), 113.

${ }^{49}$ Cf. Georgina Born and David Hesmondhalgh, eds., Western Music and Its Others: Difference, Representation, and Appropriation in Music (Berkeley, Calif. ; London: University of California Press, 2000); also see B. Heile, 'Weltmusik and the Globalization of New Music', in The Modernist Legacy: Essays on New Music (Farnham, UK: Ashgate, 2009), 101-21, http://eprints.gla.ac.uk/55054/.
} 
lines is untenable; the cosmopolitan sees degrees of familiarity and looks for sameness in the other and difference in the self.

Perhaps not surprisingly, it is predominantly religious music that attracted Bergman's attention, an interest that finds most direct expression in choral works (with or without instruments). As is well known, Bergman went on extensive travels across the world, in the process amassing a sizable collection of instruments. Hans Oesch, one of the most authoritative specialists on cross-cultural composition, accompanied him on occasion and testifies that Bergman's interest went deeper than that of a musical tourist: he learned to play various instruments and studied both primary sources and secondary literature on a range of musical traditions. ${ }^{50}$ According to Oesch, the relatively early Rubaiyat Op. 41 (1953) on texts by the great Persian poet, philosopher, astronomer and mathematician Omar Khayyam, emulates but does not imitate the maquām, the modal structures of middleEastern and Islamic musical traditions. ${ }^{51}$ This, for Oesch, differentiates the work from a superficial, merely modish reception, and instead demonstrates Bergman's endeavour to respond to musical ideas and concepts at a deep level, thereby unintentionally approaching what he calls the 'character of the universal'. ${ }^{52}$ If I cautiously agree with Oesch, it is not without noting that, in the debates on cross-cultural composition, the criteria for judgement are often back to front compared to Oesch's: one could just as well argue that only a full adoption of musical material can be regarded as 'authentic' and that any partial appropriation, as practised here by Bergman, has to be regarded as a superficial exoticism. It all depends on the wider circumstances and artistic intentions, and the kind of binary division between deep and authentic on one side and superficial exoticism on the other according to simple criteria that Oesch, like so many others, wishes to undertake may not be possible or indeed desirable. There is space between the sanctimonious condemnation as 'exoticism' or 'tourist folklore' and the celebration of perfect examples of genuine intercultural composition. What Bergman is trying is to come to terms with is otherness, to mediate between Western modernist composition and non-Western music. This should be regarded as an open process and not judged as a final outcome. What is noteworthy too is that the work came well before the discovery of non-Western music by both the American and European avant-gardes and the sometimes heated debates associated with them, so Bergman had very few models to work from.

It is interesting to note that the Rubaiyat sits between the aforementioned Espressivo and Three Fantasies in Bergman's oeuvre; in other words, it falls into the period of his most intensive investigation of dodecaphony, of which there are few if any traces in Rubaiyat. What this demonstrates is that at no stage did Bergman conceive of dodecaphony as the only legitimate musical technique, but that he always envisaged a diversity of simultaneous and, at least in principle, equally valid traditions.

\footnotetext{
${ }^{50}$ Hans Oesch, 'Exotisches Bei Erik Bergman', in Erik Bergman: A Seventieth Birthday Tribute, ed. Jeremy Parsons (Helsinki: Pan, 1981), 183-206.

51 Ibid., 188.

52 lbid.
} 


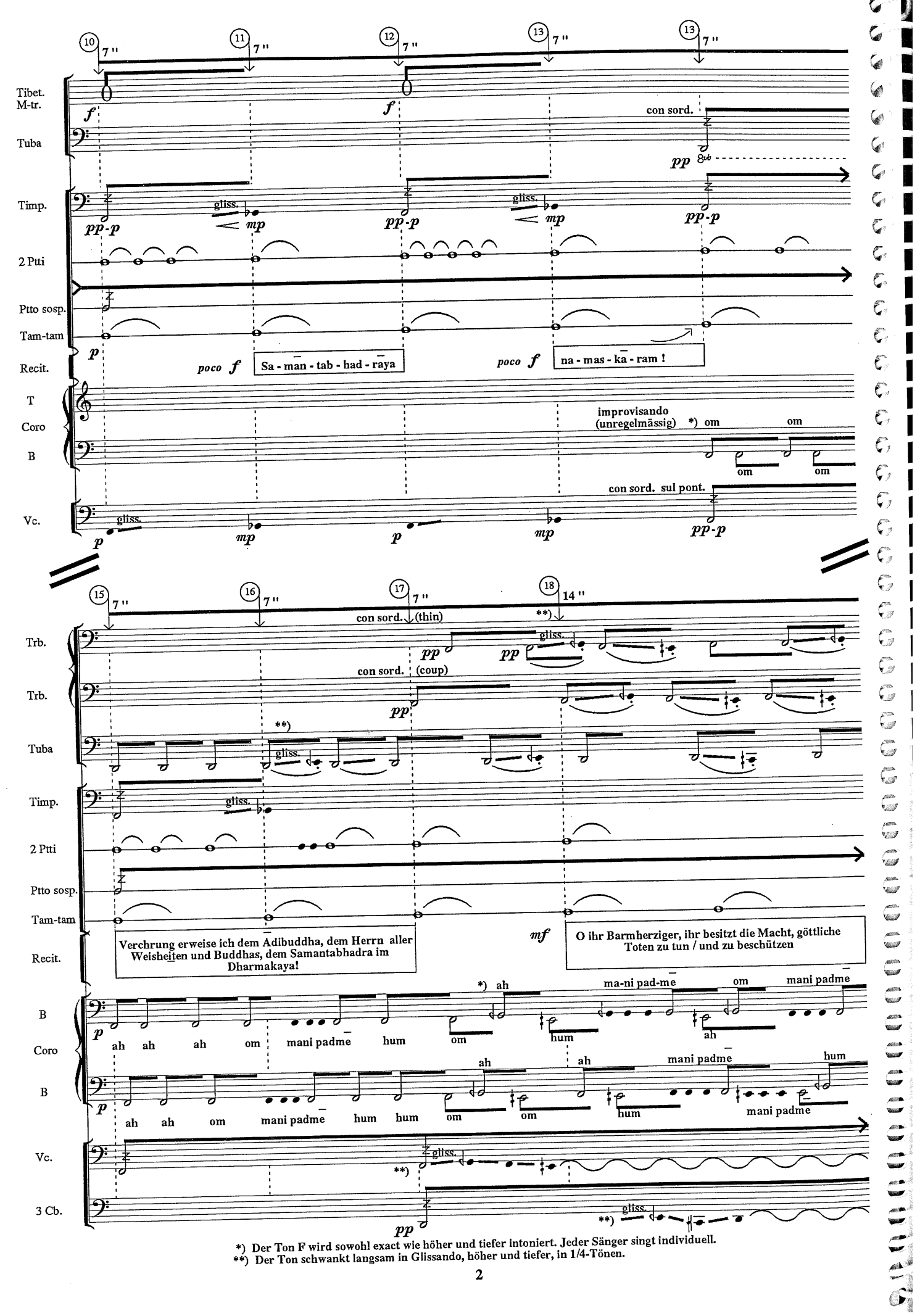

Ex. 3: Erik Bergman, Bardo Thödol Op. 74, 1st movt., bars 10ff. Reproduced by permission of Boosey \& Hawkes Music Publishers Ltd 
The apex of this strand in Bergman's work is arguably represented by the cantata Bardo Thödol Op. 74 (1974), a setting of the Tibetan Book of the Dead (see ex. 3). As Oesch states, the work is based on the actual study of rituals in Nepalese monasteries, ${ }^{53}$ so once again, it is the product of deep immersion within the culture represented. That said, I cannot deny certain reservations against the recreation of actual religious rituals, particularly death rituals, in a secular context, essentially for aesthetic delectation. Would we be happy with the enactment of Christian funerals in comparable contexts? Having said that, his period of study in Nepalese monasteries may have given Bergman reasons to feel justified in his approach.

Like his other interests, Bergman continued with his studies of musical traditions for the rest of his life. A late flowering is the dance poem Le voyage Op. 142 (1999), written as a reflection of a journey around the world with his wife-to-be (his fourth), which uses musical impressions received during various parts of the journey for the individual movements, namely Aboriginal Landscape; Maori Fantasy; Polynesian Rhythms; À la Buenos Aires; Samba; and finally South African Finale. The accusation of 'tourist folklore' is difficult to avoid, despite Bergman's life-long and undeniably deep immersion in different musical cultures and traditions.

\section{Cosmopolitanism III: Rediscovering the Self}

What these examples speak to is the endeavour to make the other the self. What is equally evident in Bergman's work, however, is the attempt to make the self other, and it is arguably this which makes Bergman a true cosmopolitan. It is only in his late phase that Bergman (re)engages with the music and sounds of his native environment or at least closer to home. As Juha Torvinen has shown, works such as Lapponia Op. 76 (1975) and Loleila Op.75 (1974) take up the yoiks of the Sami and Arctica Op. 90 (1979) and Borealis Op. 101 (1983), among many others, respond to the Nordic landscape. ${ }^{54}$ To this can be added works, such as Lemminkäinen Op. 103 (1984) and Lament and Incantation Op. 106 (1984), which, perhaps to the surprise of those who saw in Bergman only the international avant-gardist, engage with the runic chanting of the Kalevala, hitherto more likely to be associated with nationalist aesthetics. In contrast to what I have earlier described as the self-exoticising of musical nationalism, Bergman's exploration of the self is clearly informed by the experiences he gained with encountering the other. He is not interested in easily codifiable and superficial local colour but instead in uncovering genuinely strange but beautiful sounds. Listening to the bare sonorities and minute fluctuations around single notes in Lament and Incantation Op. 106 (1984) (ex. 4) for instance, with its exploration of phonetic materials

\footnotetext{
53 Ibid., 191.

54 Juha Torvinen, 'The Tone of the North', FMQ, September 2010, n.p., http://www.fmq.fi/2010/09/the-toneof-the-north/.
} 
and vocal techniques, is quite unlike any other musical experience, including that of

Incantation
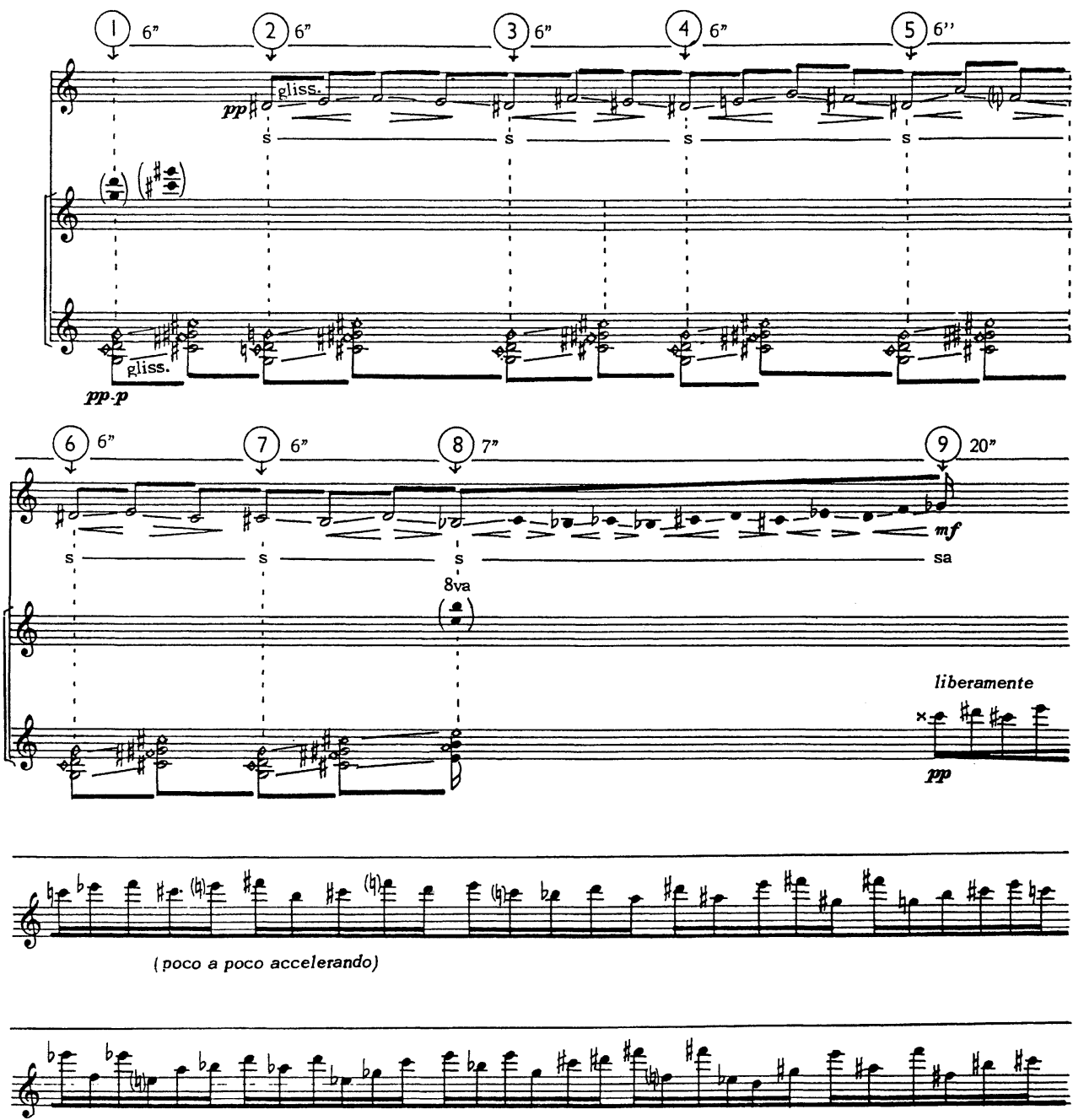

(10) $7^{n}$

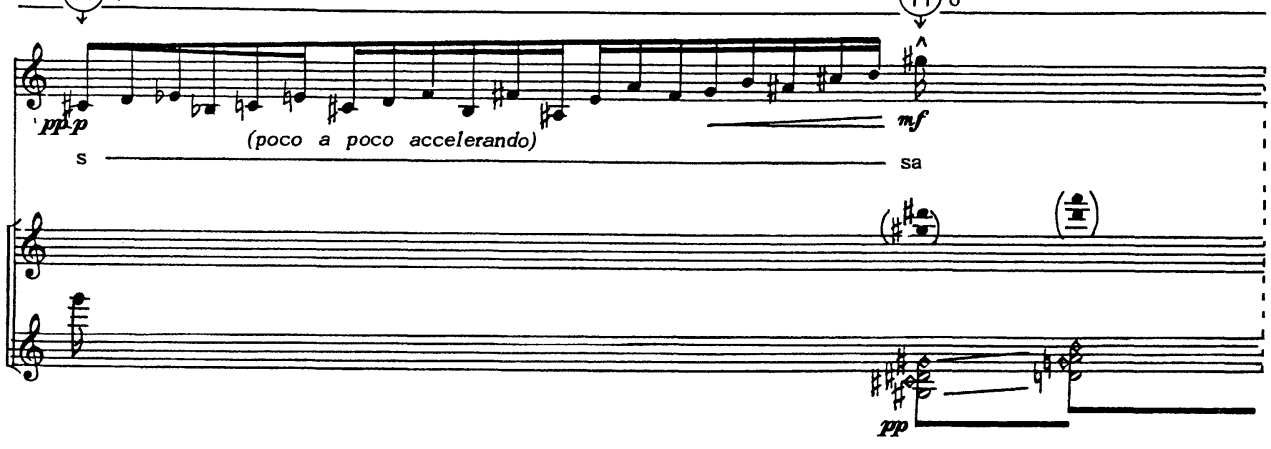

Ex. 4: Erik Bergman, Lament and Incantation Op. 106, Incantation, beginning. Reproduced by permission of Boosey \& Hawkes Music Publishers Ltd 
Bergman's own Det Sjungende Trädet, for instance, with its fluid and lyrical vocal lines which sometimes verge on the conventional and even routine. An example of an exploration of the natural environment is Borealis Op. 101 for two pianos and percussion (1983), which seems to consist of nothing but elemental noise, from the minutest murmur to a deafening roar, often changing its nature almost imperceptibly over long stretches of time.

To be clear, Bergman did not hail from the Far North, and he certainly wasn't a Sami. Nykarleby lies in central Finland (on a North-South axis) and although Bergman travelled frequently to Sápmi (the area inhabited by the Sami, formerly called Lapland), ${ }^{55}$ which played a pivotal role in his late work, he cannot be considered a local of the region. Nevertheless, there is clearly a sense in which Bergman is intently observing and listening to the world around him in one place and over long periods of time, rather than, or in addition to, travelling far and wide.

What is most striking about these late works - as of any earlier period in his career - is that instead of adjusting the musical material to his established methods and pre-conceived ideas, the composer allowed himself to be changed by it, to start afresh. As I have shown, what distinguishes pieces such as Rubaijat or Lapponia, to name works initiating a new phase or strand in Bergman's work, is that, beyond some technical features that point to Bergman's authorship, they sound radically unlike any of his, or anybody else's, earlier work.

In my view, this re-conceptualisation of the self is the true sign of the cosmopolitan. Modifying Bhabha's ${ }^{56}$ statement, one could say: cosmopolitanism must always end at home! As pointed out above, it is a common fallacy to believe that cosmopolitanism involves a denigration of local attachments in favour of lofty notions of 'world citizenship'. All that this would amount to is a dichotomy between the local and the international, which more or less reproduces the binary division between self and other characteristic of nationalism. A cosmopolitan response is the recognition that we are all locals and that we have to learn to appreciate both what we share and what is different and unique to each of us. This process requires us both to encounter the other and to look at the self through the eyes of the other, and this is what I believe Bergman's exploration of the sounds and musics of distant places and, following this, of his more immediate environment teaches us.

As pointed out above, this is not to deny problematic aspects. Clearly, questions have to be asked about Bergman's activities in Nazi Germany, his representation of the Tibetan Book of the Dead, the somewhat shallow musical snapshots of Le voyage or maybe too about his representation of the Sami and the far North. But the point cannot be a simple alternative between hagiography and sanctimony. More than anything else, cosmopolitanism involves a process of accommodation, negotiation, mediation - and learning. What characterises Bergman's approach more than anything else is going beyond what is customary and expected: beyond romantic nationalism to embrace the international avant-garde, beyond the international avant-garde to embrace the global, beyond the global to encounter the strangeness within the self.In many respects, Bergman's personal

\footnotetext{
55 Oesch, 'Exotisches Bei Erik Bergman', 183.

56 The Location of Culture, xv.
} 
development once again mirrors the wider transformations of modernist musical geography, from nationalism through internationalism, globalism to a reappraisal of the self. Yet, more than in the evolution of musical style, he is not so much retracing but anticipating and pushing beyond general developments. It is in this area too that his personal perspective, impacted as it is by his experiences as a member of the Swedish minority in Finland, with its specific history and marginal position vis-à-vis the centres of musical modernism, comes to the fore. 


\section{Bibliography}

Adorno, Theodor W. Philosophy of New Music. Minneapolis ; London: University of Minnesota Press, 2006.

Aho, Kalevi. 'Bergman, Erik'. Komponisten Der Gegenwart. 32. Lfg., 2006.

Aho, Kalevi, Pekka Jalkanen, Erkki Salmenhara, and Keijo Virtamo. Finnish Music. Keuruu: Otava, 1996. http://www.adlibris.com/fi/product.aspx?lang=fi\&isbn=9511144774.

Anderson, Martin. 'Erik Bergman [Obituary]'. The Independent, 9 May 2006. http://www.independent.co.uk/news/obituaries/erik-bergman-477409.html.

Appadurai, Arjun. Modernity at Large: Cultural Dimensions of Globalization. Public Worlds v.1. Minneapolis, Minn. ; London: University of Minnesota Press, 1996.

Appiah, Anthony. Cosmopolitanism: Ethics in a World of Strangers. 1st ed. Issues of Our Time. New York: W.W. Norton, 2006.

Beck, Ulrich. The Cosmopolitan Vision. Cambridge: Polity Press, 2006.

Bekker, Paul. Gesammelte Schriften, 1921.

-- - Neue Musik. Kraus Reprint, 1920.

Bellman, Jonathan. The Exotic in Western Music. UPNE, 1998.

Bhabha, Homi K. The Location of Culture. London: Routledge, 1994.

- - . 'Unsatisfied: Notes on Vernacular Cosmopolitanism'. In Text and Nation, edited by Laura Garcia-Morena and Peter C. Pfeifer, 191-207. London: Camden House, 1996.

Born, Georgina, and David Hesmondhalgh, eds. Western Music and Its Others: Difference, Representation, and Appropriation in Music. Berkeley, Calif. ; London: University of California Press, 2000.

Boulez, Pierre. Stocktakings from an Apprenticeship. Clarendon Press, 1991.

Breckenridge, Carol Appadurai, ed. Cosmopolitanism. Millennial Quartet. Durham [N.C.] ; London: Duke University Press, 2002.

Brooker, Peter, and Andrew Thacker, eds. Geographies of Modernism: Literatures, Cultures, Spaces. London ; New York: Routledge, 2005.

Chernilo, Daniel. 'Cosmopolitanism and the Question of Universalism'. In Routledge Handbook of Cosmopolitan Studies, edited by Gerard Delanty, 47-59. Abingdon, Oxon: Routledge, 2012.

Cohen, Brigid. 'Limits of National History: Yoko Ono, Stefan Wolpe, and Dilemmas of Cosmopolitanism'. The Musical Quarterly, 17 October 2014, gdu008. doi:10.1093/musqtl/gdu008.

-- - Stefan Wolpe and the Avant-Garde Diaspora. New Perspectives in Music History and Criticism. Cambridge: Cambridge University Press, 2012.

Cook, Nicholas. 'Introduction: Trajectories of Twentieth-Century Music'. In The Cambridge History of Twentieth-Century Music, edited by Nicholas Cook and Anthony Pople, 1-17. Cambridge: Cambridge University Press, 2004.

Corrado, Omar. Vanguardias al sur: la música de Juan Carlos Paz. Univ. Nacional de Quilmes Ed., 2012.

Crang, Mike. Cultural Geography. Routledge Contemporary Human Geography Series. London: Routledge, 1998.

Dallmayr, Fred Reinhard. Beyond Orientalism: Essays on Cross-Cultural Encounter. SUNY Press, 1996.

Delanty, Gerard. 'The Idea of Critical Cosmopolitanism'. In Routledge Handbook of Cosmopolitan Studies, edited by Gerard Delanty, 38-46. Abingdon, Oxon: Routledge, 2012.

Doyle, Laura, and Laura A. Winkiel. Geomodernisms: Race, Modernism, Modernity. Indiana University Press, 2005.

Gooley, Dana. 'Cosmopolitanism in the Age of Nationalism, 1848-1914'. Journal of the American Musicological Society 66, no. 2 (1 August 2013): 523-49. doi:10.1525/jams.2013.66.2.523.

Hannerz, Ulf. 'Cosmopolitans and Locals in World Culture'. Theory, Culture \& Society 7, no. 2 (6 January 1990): 237-51. doi:10.1177/026327690007002014. 
Heile, B. 'Weltmusik and the Globalization of New Music'. In The Modernist Legacy: Essays on New Music, 101-21. Farnham, UK: Ashgate, 2009. http://eprints.gla.ac.uk/55054/.

Heininen, Paavo. 'Erik Bergman's Path to the New Music'. In Erik Bergman: A Seventieth Birthday Tribute, edited by Jeremy Parsons, 113-50. Helsinki: Pan, 1981.

Heiniö, Mikko. 'Bergman, Erik'. Edited by Hanns-Werner Heister and Walter-Wolfgang Sparrer. Komponisten Der Gegenwart. 10. Lfg. Munich: Edition Text + Kritik, n. d.

Hobsbawm, E. J., and T. O. Ranger, eds. The Invention of Tradition. Canto. Cambridge: Cambridge University Press, 1983.

Howell, Tim. After Sibelius: Studies in Finnish Music. Aldershot ; Burlington, VT: Ashgate, 2006.

Iddon, Martin. New Music at Darmstadt: Nono, Stockhausen, Cage, and Boulez. Music since 1900. Cambridge: Cambridge University Press, 2013.

International Society for Contemporary Music. Statutes 2010. Accessed 15 December 2014. http://www.iscm.org/sites/default/files/rules_and_forms/Statutes\%202010.pdf.

Kant, Immanuel. Perpetual Peace. Filiquarian Publishing, LLC., 2007.

Korhonen, Kimmo. 'CD Booklet Meet the Composer - Erik Bergman'. Finlandia Records 4509-999642, 1996.

Kurasawa, Fuyuki. 'A Cosmopolitanism from Below: Alternative Globalization and the Creation of a Solidarity without Bounds'. European Journal of Sociology / Archives Européennes de Sociologie 45, no. 02 (August 2004): 233-55. doi:10.1017/S0003975604001444.

Levi, Erik, and Florian Scheding. Music and Displacement: Diasporas, Mobilities, and Dislocations in Europe and Beyond. Scarecrow Press, 2010.

Levitz, Tamara. 'Vogel, Wladimir'. Grove Music Online, n.d.

Locke, Ralph P. Musical Exoticism: Images and Reflections. Cambridge ; New York: Cambridge University Press, 2009.

Lutosławski, Witold. Lutosławski on Music. Rowman \& Littlefield, 2007.

Magaldi, Cristina. 'Cosmopolitanism and World Music in Rio de Janeiro at the Turn of the Twentieth Century'. The Musical Quarterly 92, no. 3-4 (21 September 2009): 329-64. doi:10.1093/musqtl/gdp021.

Minor, Ryan. 'Beyond Heroism: Music, Ethics, and Everyday Cosmopolitanism'. Journal of the American Musicological Society 66, no. 2 (2013): 529-34.

Moretti, Franco. Atlas of the European Novel, 1800-1900. London: Verso, 1998.

Mosch, Ulrich. "Ihre Lieder Sind Stimmungsvoll Und Schön, Nur...": Erik Bergmans Studien Bei Heinz Tiessen Zwischen 1937 Und 1943'. Mitteilungen Der Paul Sacher Stiftung 24 (2011): 12-18.

Oesch, Hans. 'Exotisches Bei Erik Bergman'. In Erik Bergman: A Seventieth Birthday Tribute, edited by Jeremy Parsons, 183-206. Helsinki: Pan, 1981.

Oramo, Ilkka. 'Bergman, Erik'. Die Musik in Geschichte Und Gegenwart, n. d.

Prieberg, Fred K. Handbuch deutsche Musiker 1933-1945. Fred K. Prieberg, 2004.

Revuluri, Sindhumathi. 'Review: Musical Exoticism: Images and Reflections'. Journal of the American Musicological Society 64, no. 1 (1 April 2011): 253-61. doi:10.1525/jams.2011.64.1.253.

Said, Edward W. Orientalism. Modern Classics. London: Penguin Books, 2003.

Stokes, Martin. 'On Musical Cosmopolitanism'. The Macalester International Roundtable 2007, 26 September 2007. http://digitalcommons.macalester.edu/int/rdtable/3.

Taruskin, Richard. The Oxford History of Western Music. Oxford ; New York: Oxford University Press, 2005.

-- - The Oxford History of Western Music. Oxford: Oxford University Press, 2010. http://www.oxfordwesternmusic.com.

Torvinen, Juha. 'The Tone of the North'. FMQ, September 2010. http://www.fmq.fi/2010/09/thetone-of-the-north/.

Werbner, Pnina. 'Anthropology and the New Ethical Cosmopolitanism'. In Routledge Handbook of Cosmopolitan Studies, 153-65. Abingdon, Oxon: Routledge, 2012. 
- - . 'Global Pathways. Working Class Cosmopolitans and the Creation of Transnational Ethnic Worlds'. Social Anthropology 7, no. 01 (February 1999): 17-35. doi:null.

White, John David, and Jean Christensen. New Music of the Nordic Countries. Pendragon Press, 2002. 